\title{
The pattern of protein turnover in the whole animal and the effect of dietary variations
}

\author{
By D. J. Millward and P. J. Gartick, Clinical Nutrition and Metabolism Unit, \\ Hospital for Tropical Diseases, St Pancras Way, London NWI $2 P E$
}

\section{Total body protein turnover}

Total body protein turnover is a collective property of the whole organism, in that it is comprised of the sum of the turnover rates of all the individual tissue proteins. Because of this, it has been likened to the basal metabolic rate by Waterlow (1969) who has reviewed the methodology of total turnover in the whole animal. An estimate of total body protein turnover can be obtained by determining the flux rates of an amino acid through the plasma by means of the constant infusion of a labelled amino acid (Waterlow, 1969). This has been done with lysine (Waterlow \& Stephen, 1967), tyrosine (Garlick, unpublished), and glycine (Garlick, 1969). When the flux rates are converted to total body protein turnover, rates of $40 \mathrm{~g}$ protein $/ \mathrm{kg}$ body-weight $(20 \% / \mathrm{d})$ in the young rat and $20 \mathrm{~g}$ protein $/ \mathrm{kg}$ body-weight $(10 \% / d)$ in the adult rat are obtained.

Waterlow \& Stephen (I968) measured the effect of dietary variation on lysine flux in the rat and showed that there was no more than a $15 \%$ variation in the flux rate after a variety of short-term dietary changes. In a previous paper, however, Waterlow \& Stephen ( 1967 ) showed that longer periods of protein depletion causes a $30 \%$ fall in lysine flux.

In children, protein turnover has been measured by means of the constant intragastric infusion of $\left[{ }^{15} \mathrm{~N}\right]$ glycine by Picou \& Taylor-Roberts (1969). They showed that a change in protein intake had no effect on total body protein synthesis in recovered children. However, malnourished children exhibited higher synthesis rates than recovered children. When it is considered that the malnourished child has considerably less intracellular protein than the recovered child, these results must mean that the turnover of intracellular protein is even more rapid in the malnourished child. These results therefore are quite different from those obtained with rats.

\section{The pattern of protein turnover in the whole animal}

Fig. I shows the synthesis rates of several tissue proteins measured with the constant infusion of $\left[{ }^{14} \mathrm{C}\right]$ tyrosine. In addition to the variations from 70 to $10 \% / \mathrm{d}$ shown here, there are undoubtedly other tissues with both faster (e.g. pancreas) and slower (e.g. connective tissue) synthesis rates. Protein turnover in the liver has been extensively studied and reviewed recently by Schimke (1970), Schimke \& 


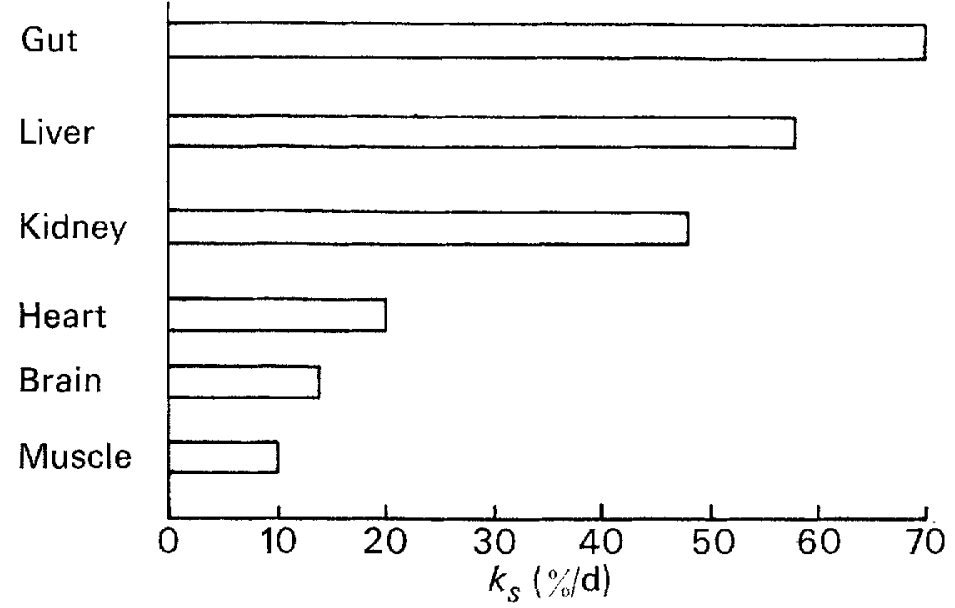

Fig. I. The rate of protein synthesis $\left(k_{s}\right)$ in different rat tissues.

Doyle (1970), and in this symposium by Hoffenberg (1972). It is important to differentiate between the proteins synthesized in the liver for 'export' - the plasma proteins; and those which do not leave the liver - the domestic proteins, since methods such as the constant infusion which lasts for $6 \mathrm{~h}$ measure only the synthesis rate of the domestic proteins.

Studies on protein turnover in the liver have shown that there is a marked heterogeneity in turnover between and within the subcellular fractions of this tissue (e.g. Arias, Doyle \& Schimke, I969). It is not known, however, to what extent this heterogeneity is present in other tissues. Chain \& Sender (1972) have reported little variation in the synthesis rates of sarcoplasmic and myofibrillar proteins in the perfused heart. In brain, Austin, Lowry, Brown \& Carter (1972) have shown that there is some variation since proteins from different layers of the cerebral cortex exhibited half-lives varying between $\mathrm{I}$ and $4 \mathrm{~d}$. In skeletal muscle the turnover rates of myofibrillar protein $(4.2 \% / \mathrm{d})$ and sarcoplasmic protein $(6.8 \% / \mathrm{d})$ are not markedly different when their functions are considered (Millward and Garlick, unpublished).

The importance of the contribution of protein turnover within a tissue to total body turnover is a function of not only the tissue protein turnover rate but also its size. Skeletal muscle is the largest single tissue in the body and as a result total muscle protein turnover is a significant part of the whole even though its turnover rate is slow.

Fig. 2 shows the distribution of protein synthesis between muscle and liver.

The distribution of protein synthesis between the tissues may change with age. This is because in tissues with a relatively slow turnover rate, such as muscle, a significant part of total protein synthesis is net synthesis or growth. Therefore as the growth rate falls with age so does the synthesis rate (Waterlow \& Stephen, 1968). Thus in the young rat the synthesis rate of mixed muscle proteins may be $15 \%$ per $\mathrm{d}$ whereas in the adult it falls to $9 \%$ per $d$. In liver and tissues with a rapid turnover rate a reduction in the synthesis rate of the same absolute magnitude will not have 


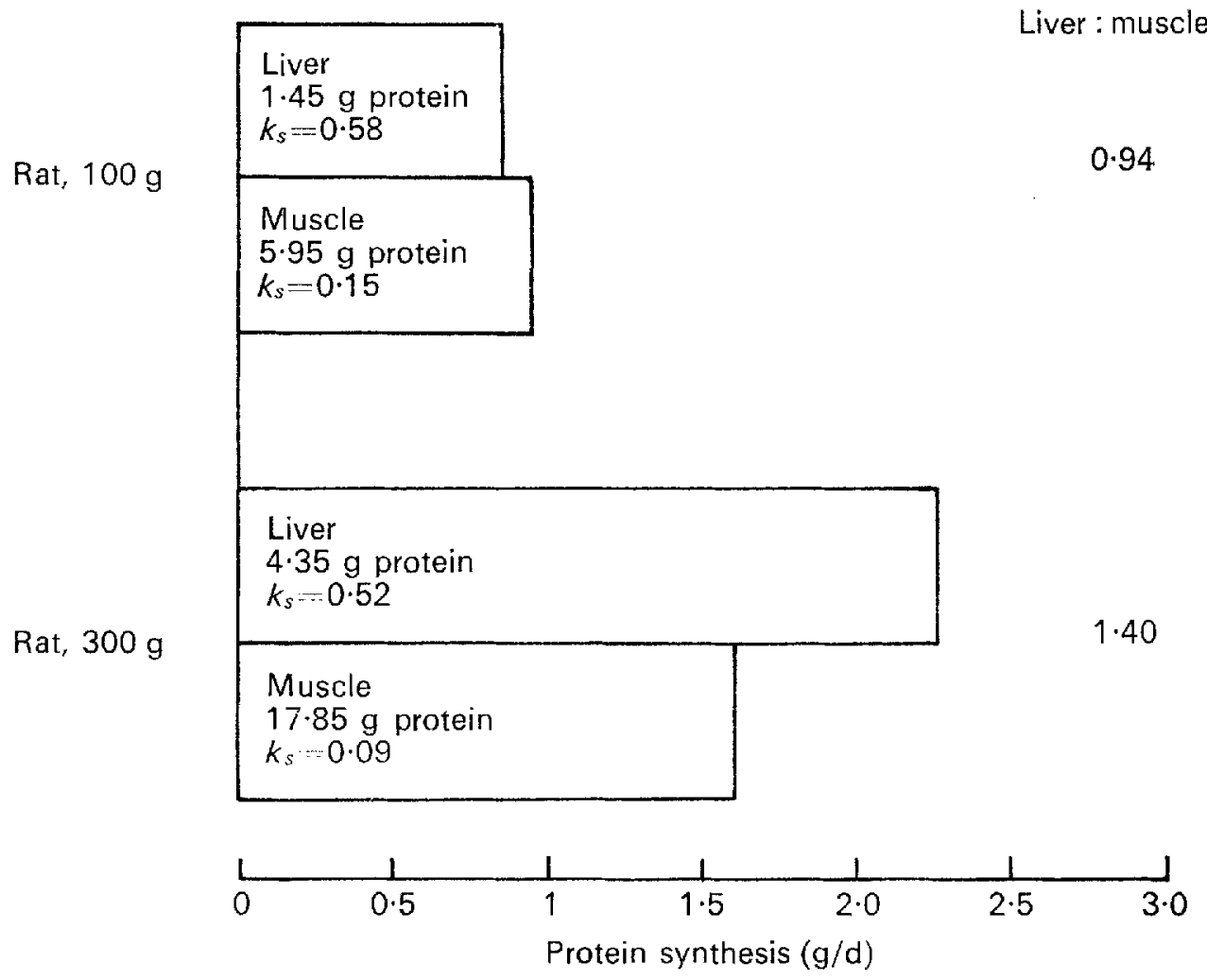

Fig. 2. The distribution of protein synthesis between liver and skeletal muscle.

the same proportional effect. Consequently, in the adult rat, protein synthesis in the liver is a larger fraction of whole body protein synthesis than is protein synthesis in muscle.

In larger animals protein metabolism in skeletal muscle is probably more important than in the rat. Skeletal muscle accounts for a constant fraction of wholebody mass as the size of the animal increases, but visceral tissues and liver especially account for a decreasing fraction. For example, Munro (I 969) has calculated the ratio of muscle to liver total RNA as an index of protein metabolism in several species and has shown that whereas it is 1.0 in the mouse the ratio is 4.4 in the horse. This may be part of the explanation for the different responses of rat and human skeletal muscle to protein depletion. In the weanling rat there is no detectable loss of muscle protein for up to 3 weeks on a protein-free diet even though the bodyweight may fall by $30 \%$ (Millward, 1972). In contrast, in man, after only an overnight fast, there is a considerable efflux of amino acids from skeletal muscle (Felig, Owen Wahren \& Cahill, i969).

The effect of food intake and protein depletion on protein turnover in liver and muscle

We have conducted several experiments designed to assess the short-term effects of feeding and food restriction on tissue protein turnover. In the first of these 
(Millward, 1970) we measured the immediate effect of a protein-free diet and starvation on protein synthesis and breakdown in liver and muscle. The results demonstrated that, in muscle, protein synthesis was more sensitive than breakdown to starvation or the protein-free regimen. On the other hand in liver, protein synthesis and breakdown were both sensitive to the two regimens.

The sensitivity of muscle protein synthesis to food intake depends to some extent on the buffering action of the liver which is interposed between the gut and the peripheral tissues (Elwyn, I970). We have investigated the immediate response of muscle-protein synthesis to feeding in rats on a cyclic feeding regimen in which they were meal-fed for $4 \mathrm{~h}$ at the beginning of each $24 \mathrm{~h}$ period (Garlick, James and Millward, unpublished). Muscle-protein synthesis, measured by the constantinfusion technique, was shown to vary throughout each $24 \mathrm{~h}$ cycle, reaching a peak between $\mathrm{r} 2$ and $\mathrm{r} 8 \mathrm{~h}$. When the rats were not fed at their normal time the synthesis rate fell so that after $24 \mathrm{~h}$ it was only $50 \%$ of the peak level. These results demonstrated that muscle is not entirely screened from the effects of food intake by the liver and also, when feeding is interrupted, muscle-protein synthesis falls very rapidly.

The effects of longer periods of depletion on tissue protein turnover have been investigated in young rats maintained on a protein-free diet for $2 \mathrm{r} d$ and then refed (Millward and Garlick, unpublished). Tissue protein synthesis rates were measured with the constant-infusion technique. In these animals there was an initial fall in the synthesis rate, which occurred immediately on feeding the protein-free diet. After Io d, however, the synthesis rate fell to an even lower level, and remained at this low level for the remainder of the experimental period. During this time no protein was lost from the skeletal muscles under study. Therefore the fall in synthesis after ro $\mathrm{d}$ must have been balanced by a fall in protein breakdown. Such a delayed fall in muscle protein breakdown is in many ways analogous to albumin which also exhibits a delayed fall in breakdown when dietary protein intake is reduced (James \& Hay, I 968).

In the liver the effects of a protein-free diet for 3 weeks are quite different. Whereas there is a fall in muscle-protein turnover, in the liver the opposite change occurs. Waterlow $\&$ Stephen (1968) have reported increases in the fractional synthesis rates of liver proteins in depleted rats and we have recently confirmed these increases (Garlick, James and Millward, unpublished).

After Io $\mathrm{d}$ on a protein-free diet the fractional synthesis rate of liver protein is increased by $50 \%$. However, in contrast to muscle the liver protein mass falls considerably during this time so that total liver protein synthesis does not change so appreciably. There is no easy explanation of this increase in the liver protein fractional synthesis rate. Albumin synthesis (not measured by the $6 \mathrm{~h}$ constant-infusion technique) falls markedly on such a regimen (Kirsch, Frith, Black \& Hoffenberg, 1968). A possible explanation of the different responses of liver 'export' and domestic protein synthesis depletion to protein is suggested by the findings of Wannemacher, Wannemacher \& Yatvin (197I) who reported an increase in the ratio of free to bound ribosomes in the livers of protein-depleted rats. An increase in the fractional 


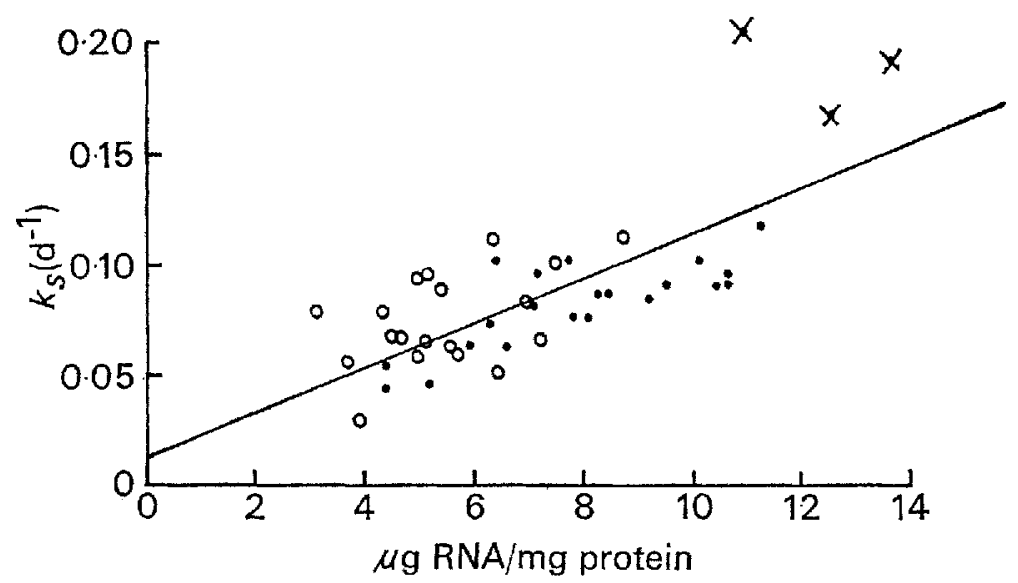

Fig. 3. The relationship between muscle protein synthesis rate $\left(k_{s}\right)$ and RNA concentration in the rat. $O$, stock diet during refeeding after $2 x \mathrm{~d}$ on protein-free diet; $x$, stock diet, controls; 9 , protein-free diet for varying periods up to $2 \mathrm{I} d$.

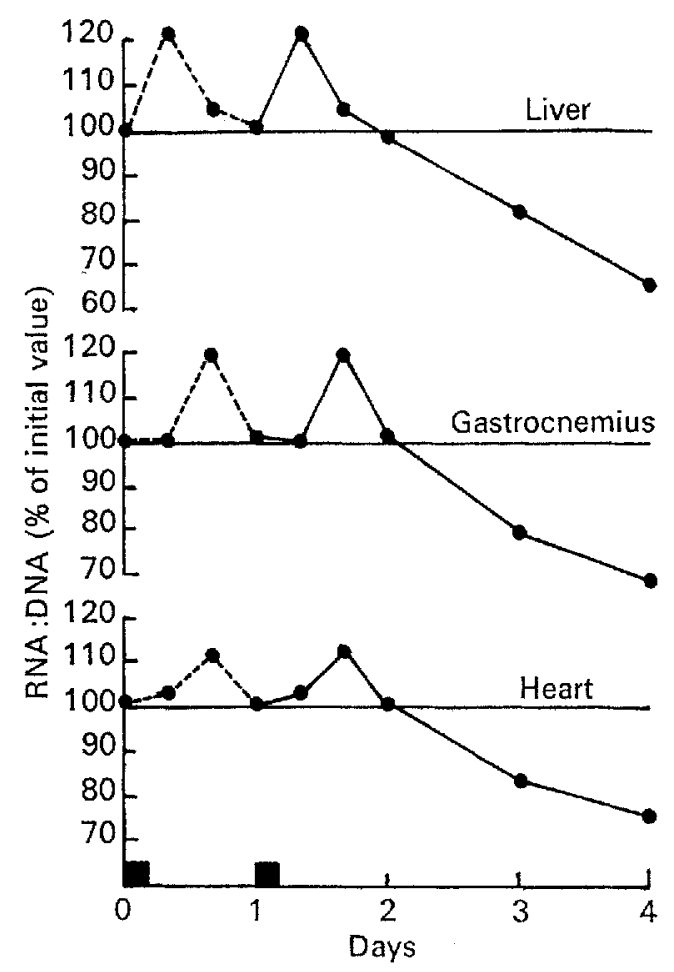

Fig. 4. Variations in RNA:DNA ratios in liver, gastrocnemius muscle and heart from rats on cyclic feeding schedules. [1, feeding times. 
synthesis rate of liver domestic proteins may well be an adaptive change to preserve liver function in times of dwindling organ mass.

During rehabilitation after long periods of protein depletion, rapid rates of catch-up growth are after achieved both in the human infant (Ashworth, 1969) and in the rat (Young, Stothers \& Vilaire, $197 \mathrm{I}$ ). If the breakdown rate, which is low in rats on a protein-free diet as discussed above, remains low during refeeding, rapid catch-up growth could occur in an economical way since most of the synthesis of tissue proteins would then be net synthesis. Young et al. (197x) have reported that the breakdown rate of muscle protein is reduced to an unmeasurably low level during catch-up growth. Indirect support for such a mechanism comes from the measurement of proteolytic enzymes in skeletal muscle. The activities of cathepsin $\mathrm{D}$ and the alkaline autolytic enzyme in muscle during refeeding have been shown to be reduced (Millward, 1972). However, the relevance of these proteolytic enzymes to normal intracellular proteolysis is not known.

The intensity of protein synthesis in a tissue is a function of the concentration of the translational apparatus (i.e. RNA) and the efficiency with which translation occurs (i.e. protein synthesis:RNA). Fig. 3 shows the relationship between muscle protein synthesis and RNA concentration in muscle from rats on a protein-free diet for up to 3 weeks and during refeeding. The obvious correlation between the synthesis rate and the RNA concentration indicates that, when the diet is changed, whatever the primary event which effects the change in protein synthesis, the RNA concentration also changes. Furthermore, the extent to which individual results vary from the over-all correlation reflects the extent to which the efficiency of protein synthesis (as defined above) changes. It is of interest that most of the results above the line (i.e. showing increased efficiency) are from the refed or control rats, whereas the results from the protein-free rats tend to lie below the line.

The RNA concentration in the liver varies diurnally (Potter, Baril, Watanabe \& Whittle, I968). Fig. 4 shows that in cardiac and skeletal muscle of rats meal-fed on a cyclic feeding regimen, diurnal rhythms of RNA:DNA ratios also occur. Furthermore, when the animals were not fed, RNA was lost from liver, heart and skeletal muscle at similar rates. The implication of these results, that the variations in tissue RNA concentrations (and consequent availability of ribosomes) are closely related to changes in the rate of protein synthesis, should at first sight be obvious. However, in a recent review of the regulation of protein synthesis (Munro, 1970) it was stated that the availability of ribosomes was not considered to be rate-limiting in protein synthesis.

\section{REFERENCES}

Arias, I. M., Doyle, D. \& Schimke, R. T. (1969). F. biol. Chem. 244, 3303.

Ashworth, A. (1969). Nature, Lond. 223, 407.

Austin, L., Lowry, O. H., Brown, J. G. \& Carter, J. G. (1972). Biochem. F. 126, 35 I.

Chain, E. B. \& Sender, P. M. (1972). Biochem. J. 129, 13P.

Elwyn, D. E. (1970). In Mammalian Protein Metabolism Vol. 4, p. 523 [H. N. Munro, editor]. New York and London: Academic Press.

Felig, P., Owen, O. E., Wahren, J. \& Cahill, G. F. Jr (1969). F. clin. Invest. 48, 584.

Garlick, P. J. (1969). Nature, Lond. 223, 61. 
Vol. 3 I Amino acid supply and polynucleotide and protein metabolism 263

Hoffenberg, R. (1972). Proc. Nutr. Soc. 3r, 265.

James, W. P. T. \& Hay, A. M. (1968). F. clin. Invest. 47, 1958.

Kirsch, R., Frith, L., Black, E. \& Hoffenberg, R. (1968). Nature, Lond. 217, 578.

Millward, D. J. (1970). Clin. Sci. 39, 591.

Millward, D. J. (1972). Proc. Nutr. Soc. 31, 3 A.

Munro, H. N. (editor) (1969). In Mammalian Protein Metabolism Vol. 3, p. 167. New York and London: Academic Press.

Munro, H. N. (editor) (1970). In Mammalian Protein Metabolism Vol. 4, p. 75. New York and London: Academic Press.

Picou, D. \& Taylor-Roberts, T. (1969). Clin. Sci. 36, 283.

Potter, V. R., Baril, E. F., Watanabe, M. \& Whittle, E. D. (1968). Fedn Proc. Fedn Am. Socs exp. Biol. 27, I 238.

Schimke, R. T. (1970). In Mammalian Protein Metabolism Vol. 4, p. I78 [H. N. Munro, editor]. New York and London: Academic Press.

Schimke, R. T. \& Doyle, D. (1970). A. Rev. Biochem. 39, 929.

Wannemacher, R. W. Jr, Wannemacher, C. F. \& Yatvin, M. B. (1971). Biochem. F. 124, $3^{85}$.

Waterlow, J. C. (1969). In Mammalian Protein Metabolism Vol. 3, p. 325 [H. N. Munro, editor]. New York and London: Academic Press.

Waterlow, J. C. \& Stephen, J. M. L. (1967). Clin. Sci. 33, 489.

Waterlow, J. C. \& Stephen, J. M. L. (1968). Clin. Sci. 35, 287.

Young, V. R., Stothers, S. C. \& Vilaire, G. (1971). F. Nutr. I01, I379. 